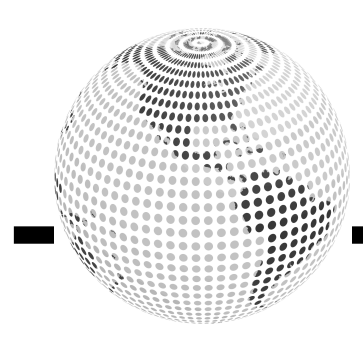

\title{
Indo-Pakistani Enmity and the Reorganization of Asia
}

Strategic Opportunities for China and India

Soleine Leprince-Ringuet

Sciences Po Paris- London School of Economics, 2009

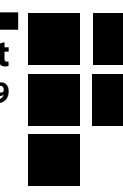

South Asia is not in itself the primary zone of interest of China. However, China has since long used the region's dynamics to achieve some of its most important strategic goals. Moreover, since India wishes to establish "its rightful place in the emerging world order", South Asia may soon gain in strategic importance. The region being dominated by the enmity between Pakistan and India, China must strategically choose its position on the conflict.

How does China use the Indo-Pakistani tensions to achieve its strategic goals? And how may India redefine its stances in the region to advance its own strategic agenda?

The Indo-Pakistani tensions represent an opportunity for China to increase its leverage on the region, because both Pakistan and India are very sensitive to the positioning of foreign powers. But new events- the end of the Cold war, the nuclear tests and the beginning of the war on terror - forced China to reassess both its strategic interests and its position on the India-Pakistan conflict. Several contemporary developments may lead China to adopt a stance more favorable to India. India itself is now "a swing state" that can choose among several options how to diminish the importance of the Pakistani factor and reorganize Asia.

\section{Centrality of the Indo-Pakistani enmity in strategic thought about South Asia}

In this section we show how central Pakistan still is in India's strategic thinking. Despite India's wish to be a regional power, whoever wishes to deal with India must first adjust his stance on Pakistan.

\section{Pakistan's preeminence in India's strategic thinking}

Since its very creation in 1947, "India's ambition to play a global role has been constrained by interstate rivalry within the subcontinent" (Nayar). India's concern for Pakistan is itself a puzzle : Why does India feel encircled and threatened, when it is seven times more populous, five times larger, and has the second largest army in the world? The response is that Pakistan's very identity is a threat to India's integrity.

The Indo-Pakistani dispute is a leftover from decolonization: Under the partition plan of 1947, Kashmir was free to accede to India or Pakistan. Its prince Hari Singh finally decided to accede to India despite Kashmir's Muslim majority. But Pakistan believes that its State will remain incomplete until the country -established as a homeland for Muslims - receives all Indian lands where Muslims are the majority. India refuses this claim, asserting that it is the very existence of Indian Muslims which preserves the secular nature of the Indian state.

From the time of its establishment, Pakistan's worldview has been dominated by the perception that it faces an existential threat from its enormous neighbor (Gill). This perception pervades all aspect of Pakistan government's policy, to the detriment of economic and social considerations. Hence Pakistan is now a land of poverty and of high social instability, characterized by an "unworkable unitary system of government, and the alienation of Pakistan's rulers from their people" (Cohen). But Pakistan is an interesting partner for China strategically. Pakistan is located in the region where South 
Asia converges with the Middle East and Central Asia; its coastline along the Arabian Sea is about 650 miles long.

Obsessed by national security, Pakistan relies on external allies to bolster its own defenses through arms supplies and diplomatic support.

\section{Will India's new ambitions lead to peace?}

Since 1998, India has shown increasing assertiveness on the Asian scene. India's "globally activist diplomacy provides the impression of a country that [is] beginning to matter" (Limaye). India has the ambition to become a mighty regional player thanks to high rates of economic growth. But India must also learn to conduct its foreign policy as a major Asian power and not just as a South Asian state.

Consequently, India now considers that peace with Pakistan would enhance its standing in the international system (Nayar), a reason that can explain the inauguration of a peace process in 2004. However, since the Simla Agreement of 1972, New Delhi advocates for a purely bilateral resolution of the conflict. A bilateral resolution is highly unlikely, though, as both sides keep rigid positions, with Pakistan still asking for a plebiscite and India claiming the unacceptability of border change.

\section{Other regional powers deal strategically with a zero-sum game}

Even as India tries to assert itself in Asia, it is extremely sensitive to any move of a regional player towards Pakistan. One can model this situation as a zero sum-game, where any positive gain with Pakistan constitutes a loss in the country's relationship to India.

Hence the strategic thinking of a regional actor towards India is inevitably linked to its strategic thinking towards Pakistan and vice versa: "the most consistent policy in both states for over fifty years has been to seek outside allies against each others"(Cohen). The conflict therefore enhances the opportunity for outside powers to intrude and exert leverage on the region. How has China dealt with this quasi zero-sum game to achieve its strategic goals? What were the main turning points that transformed its strategic thinking towards India and Pakistan?

\section{Turning points, new strategic goals and the transformation of the Indo- Pakistani issue}

In this section, we examine how the end of the Cold war, the nuclear tests and the war on terror were three major tuning points that changed the strategic goals of China and its stance on the Indo-Pakistani conflict.

\section{The end of the Cold War changes the very nature of the conflict}

During the ColdWar, the Indo-Pakistani conflict was seen as part of the struggle between the East and the West. Pakistan was backed by the United States and China. Beijing saw its relationship to Pakistan as fulfilling a double mission, resisting the Soviet Union and creating a two-front threat to India (Deepak): The internecine feud with Pakistan pulled India down to the level of Pakistan to China's benefit. Therefore after 1965, Beijing provided more military assistance to Pakistan than it has to any other state.

In response, India, first non-aligned, strategically moved closer to the Soviet Union, hoping to fall under the superpower's protection. The Indo-Pakistani conflict was endemic to the Cold War.

But the end of the Cold War changed the very nature of the conflict. China's strategic interest in Pakistan declined, as balancing Russia was no longer a priority. The ties between India and Russia also went through a steep decline because balancing China was no longer a Russian strategic goal. The IndoPakistani conflict temporally became a South Asian conflict.

The nuclear tests give the conflict a new scale and call for the reassessment of India

India's nuclear testing in May 1998 was 
a highly strategic move to demonstrate India's new assertiveness. Surprisingly, Indian Prime Minister Vajpayee used the Chinese threat as a justification for the test, writing to Bill Clinton that "India had an'overt nuclear weapons' state on its borders, which was materially helping another neighbor". Why would India do so when its ties with China were improving? India used this strategic move to appear as capable of challenging China, finally looking out of South Asia. India was also hoping to find allies sensitive to this Chinese threat, such as the US and Japan.

The nuclear tests had a great impact on Chinese strategic thinking. Of course, China, wishing to stay the only legitimate nuclear weapon state in Asia, first accused India of seeking "hegemony in the South". But China then became reluctant to support Pakistan, and defended India's stance that the problem be dealt with bilaterally. Why this shift? First, the nuclear tests led China to the reassessment of India's importance (Rajamony). China became increasingly concerned with normalizing its ties with India. Second, advocating "self-determination" could play against China's own strategic interest concerning the South China Sea islands. Third, China moderated its stance on Kashmir because China desired to appear as "a peace-making moderate" in order to be coherent with its "peaceful rise" paradigm (Cohen).

\section{The war on terror, an opportunity for new alliances with India and Pakistan}

September 11 represented a third major shift in the strategic thinking of China and India. Strategically, Pakistan chose to cooperate with the US: "By aligning with the United States in the global war on Terror, Pakistan prevented itself from being viewed, and treated, as part of the terrorist problem"(Andersen). Pakistan, inconsequence, greatly improved its international status.

But the US tried to avoid the previous zero-sum character of US policy towards India and Pakistan by establishing in 2004 a"strategic partnership" with India that would "expand cooperation" in civilian nuclear activities, high technology trade, missile defense, etc.probably in the hope to balance China.

This new "global partnership" between India and the United States, and the strengthening of the Japan-India relations (the Eight-fold Initiative for Strengthening JapanIndia Global Partnership in 2005) worried China. China acquired an observer status in the SAARC, partly in order to balance India. Does this mean that China will go back to siding openly with Pakistan in order to balance India? Probably not.

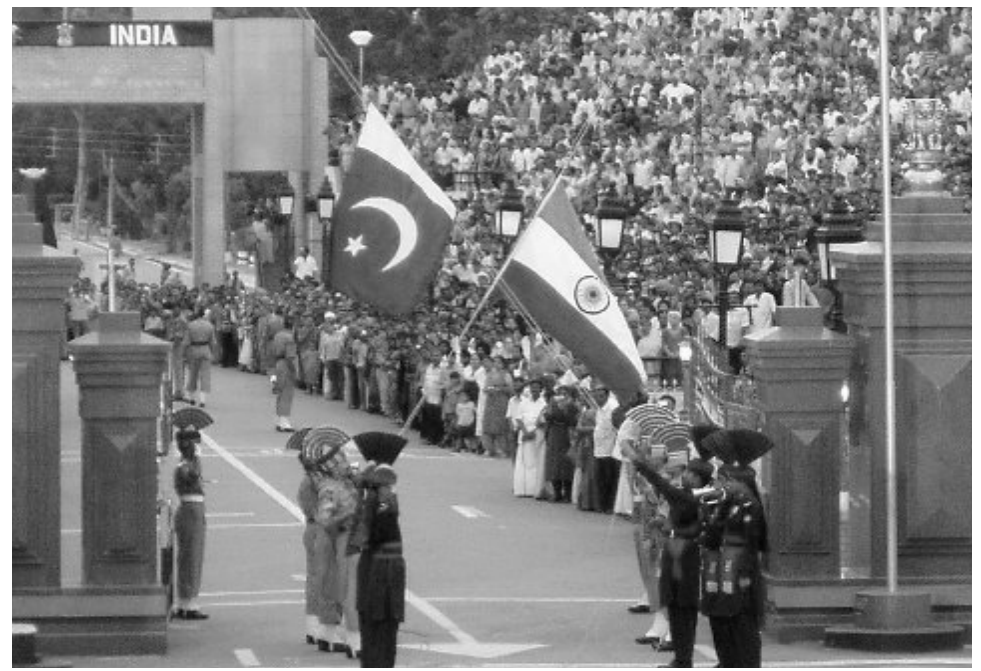


Current issues could lead to a situation more favorable to India at the expense of Pakistan

Economic concerns and regional frameworks are now important issues that could enhance India's appeal at the expense of Pakistan in the strategic thinking of China. However, this will largely depend on India's own strategic choices among the different options for the reorganization of Asia.

\section{How could India's rise play out on the Indo- Pakistani conflict?}

Beijing likes to say that economic development is now its first priority. As India develops, India becomes an attractive market for Chinese goods- more than Pakistan could probably ever be. In November 2006, China signed a free trade agreement (FTA) with Pakistan that aims to triple bilateral trade in the next five years. But Pakistan's GDP growth (around $4.5 \%$ ) is slower than that of India, and the country suffers from instability and inflation. If India maintains its faster development, China might decide to increase its ties to India at the expense of Pakistan, though this is still uncertain: China could see India as a competitor rather than a partner.

The current political situation of Pakistan is another factor that could lead China to become more favourable to India. Pakistan was suspended from the Commonwealth of Nations on November 22, 2007, three weeks after President Musharraf imposed martial law. The assassination of Benazir Bhutto on December 27, 2007, leader of the Pakistan Peoples Party (PPP), also hints that the road to democracy will be long and difficult. Though the PPP emerged as the largest party on February 18,2008 , no political party was able to secure a majority in the Parliament. With Musharraf refusing to resign despite his party's bad results, it is unclear whether the unpopular present will be able to govern the country. The violence of Pakistani politics also seems to have become enduring. For instance, less than one week after the elections, the surgeon general of the Pakistani Army, Mushtaq Ahmad Baid was killed in a suicide attack. Because Pakistan currently gives the impression of an unstable and violent country, India may appear as an increasingly interesting partner to China.

\section{Opportunities for increased regionalism and consequences on the Indo-Pakistani conflict}

China and Japan both wish to increase regionalism in Asia, but they compete as to how to design this regional framework. Since the formation of ASEAN +3 in 1997, Japan has found China's voice too powerful in the forum. In consequence Japan has strengthened its alliance with the US and called for "open regionalism", materialized in 2005 by the formation of the East Asian Summit (EAS) that included Australia, New Zealand and India. The inclusion of India strategically made it more difficult for China to lead unilaterally (Rozman). Moreover, Japan wanted these inclusions to increase the importance of democracy in the framework, hoping to isolate China. This may play out on the Indo-Pakistani issue: If Japan becomes increasingly concerned about supporting democracy in Asia, this will play in the favor of India at the expense of Pakistan.

China, however, perceived that Japan wished to counter its importance, and therefore has become wary of the EAS and of Japan's plan to create a democratic Japan-USIndia-Australia axis. China could try to avoid the formation of such a quadrangle by moving closer to India, distancing itself from Pakistan.

How could India reorganize the region? India's multiple options regarding Pakistan and their consequences

If it is difficult to foresee China's future positioning on the Indo- Pakistani issue, it is because India is itself an increasingly essential actor, capable of choosing how Asia may be reorganized. To become a global power, India must decrease the importance of Pakistan in its strategic thinking, so that "It would not be a question as it is now of Indian power minus Pakistani power, but of an India free to exercise 
its influence over a much wider range" (Cohen). India has many options to do so. First, it could ease the tensions with Pakistan by engaging the country through the multiplication of economic ties. In 2000, trade with Pakistan constituted only $0.21 \%$ of India's total trade, and trade with India was $1.25 \%$ of Pakistan's total trade (Sridharan). More economics links could produce a spill-over into security-issues and put an end to India's paranoia.

Other options seek not to engage but on the contrary to further isolate Pakistan to diminish its strategic importance. India can continue to engage China hoping that it will abandon Pakistan. If India manages to untie the Sino-Pak "entente cordiale", Primakov's concept of an India-Russia-China triangle of cooperation might even become successful.

Alternatively, to push aside the burden of Kashmir, India could make better use of the existing regional frameworks: It could develop continental ties with the SCO and maritime ties with the EAS to isolate Pakistan.

Last, India could isolate Pakistan by becoming closer to Japan at the expense of China. Eventually it could form a democratic axis US- Japan- Australia- India to isolate non-democratic countries such as China and Pakistan. India could then loosen its "one China foreign policy" and develop closer ties to Taiwan. "A healthy relationship with Taiwan will not only further its own strategic and economic interests but also checkmate
China"(Nanda).

These different options show that India has become the "swing state" (Gupta) that can make important decisions about the reorganization of Asia. Yet when choosing among these options, India will surely examine which one offers the most guarantees against the Pakistani threat- only then may India become an Asian power.

The "Pakistani factor" has been the main concern shaping India's foreign policy since 1947. China has recognized the structural nature of the Indo-Pakistani enmity and exploited it to its advantage. With the end of the Cold War, the nuclear tests and the War on terror, the conflict's very nature has changed and China has adapted its stance on the conflict to its evolving strategic interests. Current issues of importance, such as economic development and regionalism suggest that China may choose a stance more favorable to India at the expense of Pakistan. But this will depend critically on India's own strategic choices. India has indeed increasingly become an actor, "a swing state" capable of choosing among different options for the reorganization of Asia which one will best diminish Pakistan's strategic importance. Only once India becomes less "Pakcentrik" will India be able to become an Asian power and find "its rightful place in the emerging world order."

\section{Works Cited}

-Andersen, W., Recent trends in Indian foreign policy, Asian Survey, Vol 41, 2001

-Andersen, W. South Asia: a selective war on terrorism IN Strategic Asia 2004-05, ed. by A. Tellis et al, Washington, DC: National Bureau of Asian Research, pp. 227-59

-Bouton, M, Oldenburg,P. India Briefing, A transformative fifty years, 1999

-Cohen, S. India : Emerging Power, Brookings Institution Press, 2001, Washington

-Deepak B.R., Sino-Pak "Entente Cordiale" and India : A look into the Past and future. China Report, 2006

-Gill, J. India and Pakistan IN Strategic Asia 2005, Seattle, WA: National Bureau of Asian Research, 2005/05, pp. 237-267

- Gupta, A., US-India-China, Assessing Tripolarity, China Report, 2006 Vol 42, New Delhi

-Limaye, S.P, Tokyo's Dynamic Diplomacy: Japan and the Subcontinent's Nuclear Tests, Contemporary Southeast Asia, Vol. 22,2000

-Lounev, S. Russian-Indian relations in Central Asia IN Islam, oil and geopolitics, ed. by E. Davis et al., Lanham, MD: Rowman and \&Littlefield, 2007, chapt. 12, pp. $173-86$

-Malik, M., The China factor in the India Pakistan Conflict, Parameters, 2003

-Nayar, B. India in 2005: India rising, but uphill road ahead Asian survey, vo. 46, no. 1, Jan/Feb 2006, pp. 95-106

-Nanda, P., India and its Taiwan Policy, China Brief. Vol 3 , 2003-Raman, B., India, Japan \& China, talk delivered on April 27, 2007, South Asia Analysis group

-Rajamony, V., India-China- US triangle, A soft Balance of Power System in the Making? Centre for Strategic and International Studies, 2002

-Rozman, G., Japanese strategic thinking on Regionalism, IN Japanese Strategic Thought toward Asia, edited by Gilbert Rozman et al, New York, NY: Palgrave Macmillan, 2007

-Sinha, S., The Strategic Triangle India China Pakistan, China Report, 2004

-Sridharan, E.Improving Indo-Pakistan relations; international relations theory, nuclear deterrence and possibilities for economic cooperation, Contemporary South Asia, September 2005 